\title{
Geoelectric Soundings for Delineation of Saline Water Intrusion into Aquifers in Part of Eastern Dahomey Basin, Nigeria
}

\author{
Igbagbo A. Adeyemo*, Gregory 0. Omosuyi, Adebowale 0. Adelusi \\ Department of Applied Geophysics, Federal University of Technology, Akure, Nigeria \\ Email:*adeyemoia@yahoo.com
}

How to cite this paper: Adeyemo, I.A., Omosuyi, G.O. and Adelusi, A.O. (2017) Geoelectric Soundings for Delineation of Saline Water Intrusion into Aquifers in Part of Eastern Dahomey Basin, Nigeria. Journal of Geoscience and Environment Protection, 5, 213-232.

https://doi.org/10.4236/gep.2017.53015

Received: December 7, 2016

Accepted: March 28, 2017

Published: March 31, 2017

Copyright $\odot 2017$ by authors and Scientific Research Publishing Inc. This work is licensed under the Creative Commons Attribution International License (CC BY 4.0).

http://creativecommons.org/licenses/by/4.0/

\begin{abstract}
This study was aimed at mapping the subsurface extent of saline water intrusions into aquifers at the eastern part of Dahomey basin, Nigeria. The study adopted geoelectric sounding methods. 108 vertical electrical soundings (VES) and 9 induced polarization soundings (IPS) data were acquired using Schlumberger array technique. Three aquifer units were delineated across the study area. The resistivity of the first, second and third aquifer layers varies from 0.2 to $1569 \mathrm{ohm}-\mathrm{m}, 0.5$ to $904 \mathrm{ohm}-\mathrm{m}$ and 0.4 to $665 \mathrm{ohm}-\mathrm{m}$ respectively, while depth to the top of first, second and third aquifer varies respectively from 0.7 to $151.5 \mathrm{~m}, 1.4$ to $305.5 \mathrm{~m}$ and 12.9 to $452.9 \mathrm{~m}$. The depth to the first aquifer layer is shallow (less than $5 \mathrm{~m}$ ) in the coastal area which makes this area to be highly vulnerable to anthropogenic pollution while their proximity to Atlantic Ocean makes them susceptible to saline water intrusion. In all the three aquifer units, the coastal area, Agbabu and other few locations in the mainland are characterized by low resistivity values (below $60 \mathrm{ohm}-\mathrm{m}$ ) indicating possible presence of brackish or saline water. IP sounding results showed that all the low resistive layers in the mainland are characterized by clayey materials. The integration of VES and IPS results enabled the delineation of the saline water lateral extent across the study area. There is a strong direct correlation $\left(r^{2}=\right.$ 0.8564 ) between location distance from the saline water source and depth to saline water in the study area. This can therefore serve as a predictive model to determine depth to saline water at any location within the saline water zone in the study area.
\end{abstract}

\section{Keywords}

Saline Water Intrusion, Saline-Freshwater Boundary, Vertical Electrical Sounding (VES), Induced Polarization Sounding (IPS), Correlation Curve 


\section{Introduction}

Groundwater resources have now become major sources of fresh water in Nigeria and many African countries. This is largely due to the fact that government at all levels are no longer paying attention to construction of dams for production of potable water for public use, hence most Nigerians depends on groundwater abstraction through construction of hand dug wells and boreholes. One major environmental problem regularly confronting continental areas adjoined by oceans is saline water intrusion into the coastal/continental aquifer. This has been reported by several authors across the world [1]-[10]. Not much works have been done on saline water intrusions in the study area. Low resistivity layers suspected to be saline/brackish water intrusion into the aquifers in the area were earlier delineated [11] [12] [13]. In other part of the eastern Dahomey basin, Lagos State, Nigeria, combination of electrical resistivity and induced polarization methods were used [14] [15] [16]; while in another work [17] water physicochemical analysis and electrical resistivity tomography were integrated in the study of possible saline water intrusion into the area. In all these studies, low resistivity values suggesting saline/brackish water, or clayey layers were delineated. This study represents the first major attempt to delineate saline water intrusion into aquifers in the study area with a considerable large data set.

\section{The Study Area}

\subsection{Description of the Study Area}

The study area stresses across six Local Government councils in the southern part of Ondo and Ogun States, South Western Nigeria. It is bounded by the following coordinates: longitudes $4^{\circ} 22^{\prime} 22.5^{\prime \prime} \mathrm{E}$ and $5^{\circ} 10^{\prime} 2.0^{\prime \prime} \mathrm{E}$ and latitudes $5^{\circ} 50^{\prime} 44.1^{\prime \prime} \mathrm{N}$ and $6^{\circ} 39^{\prime} 39.5^{\prime \prime} \mathrm{N}$ and it covers a total area of about $4200 \mathrm{~km}^{2}$ (Figure $1)$. The area is generally characterized by flat and gently undulating topography. The elevations vary between 13 to $83 \mathrm{~m}$ above sea level in the mainland and 2 to $10 \mathrm{~m}$ in the coastal area (Figure 2).

\subsection{Geology of the Study Area}

The study area is underlain by the sedimentary sequence of the Dahomey basin. The Dahomey Basin stretches from south-eastern Ghana to south-western Nigeria. It is separated from the Niger Delta by the subsurface basement high (Okitipupa Ridge) around Okitipupa in Ondo State, Nigeria [18] [19]. Dahomey basin contains extensive wedge of Cretaceous to recent sediments, which thicken towards the offshore [20] (Figure 3). Six lithostratigraphic units have been identified by various workers. The formations from the oldest to the youngest includes: Abeokuta Group (Cretaceous), Ewekoro Formation (Paleocene), Akinbo Formation (Paleocene-Eocene), Oshosun Formation (Eocene), Ilaro Formation (Eocene) and Benin Formation (Oligocene-recent). The known aquifers in the study area are mostly within the Benin Formation [21]. The formation consists of unconsolidated, poorly sorted sands with lenses of clayey shale [22]. 

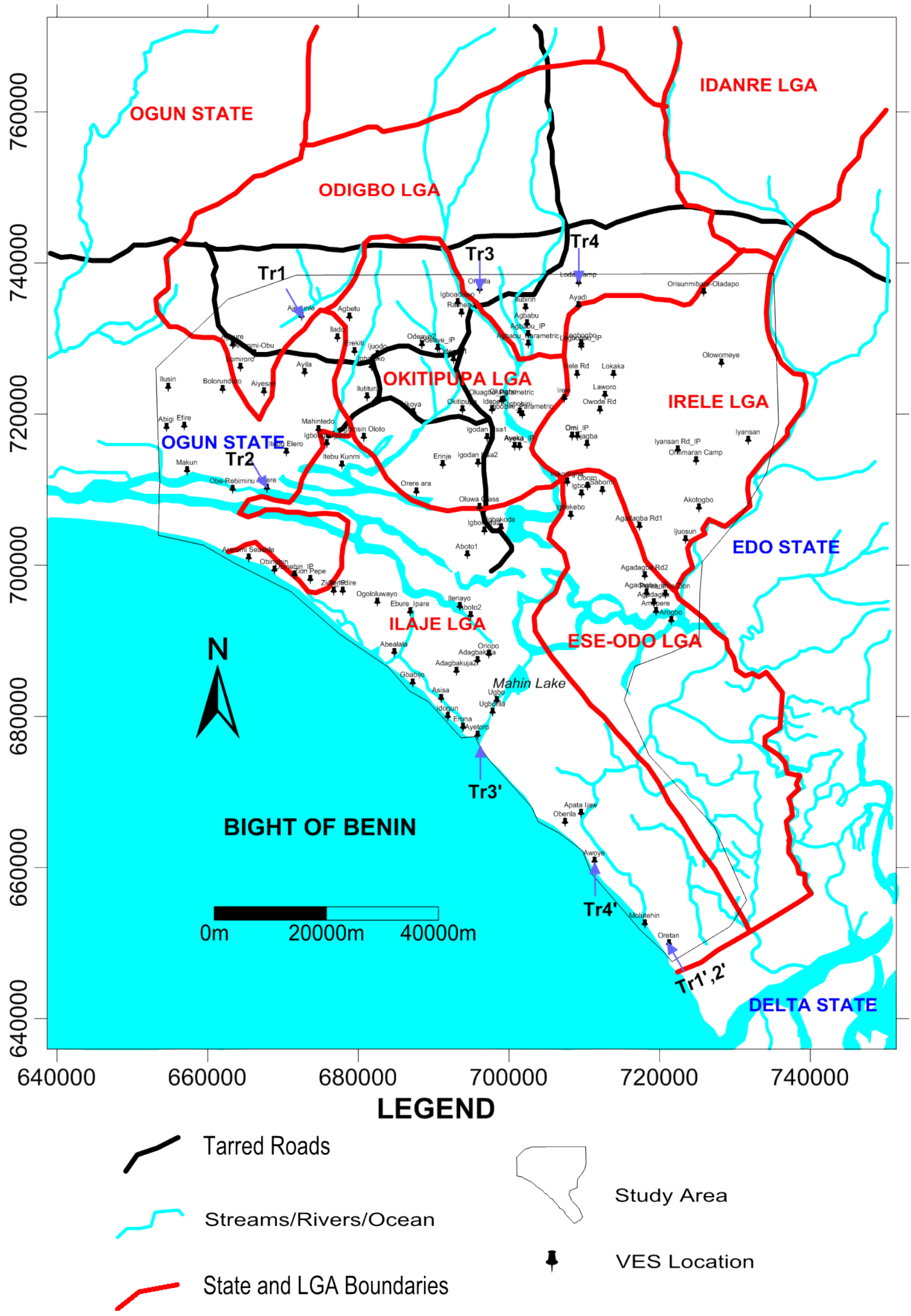

Study Area

4 VES Location

Figure 1. Location map of the study area showing VES locations. 


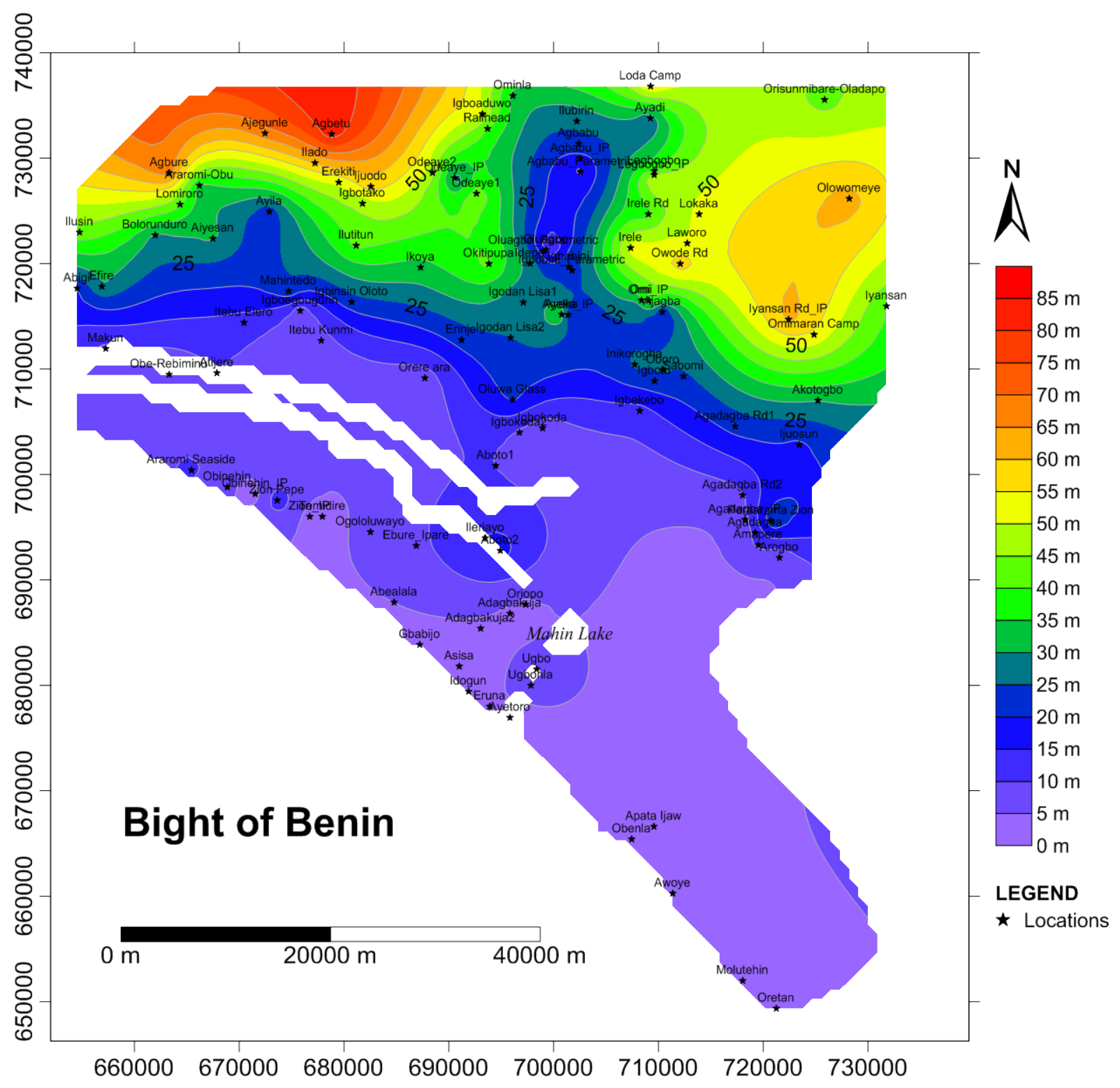

Figure 2. Topographic map of the study area.

\section{Methodology}

The study adopted geoelectric sounding methods. A total of 108 vertical electrical soundings (VES) and 9 induced polarization sounding (IPS) data were acquired using Schlumberger array technique (Figure 1). The maximum current electrode separation $(\mathrm{AB} / 2)$ was varied from 225 to $750 \mathrm{~m}$. The field data were interpreted using the conventional partial curve matching technique supported with computer iteration. The VES and IPS results are as presented in Table 1 and Table 2 respectively.

\section{Discussion of Results}

Maximum of eight geoelectric layers were delineated across the study area. The 

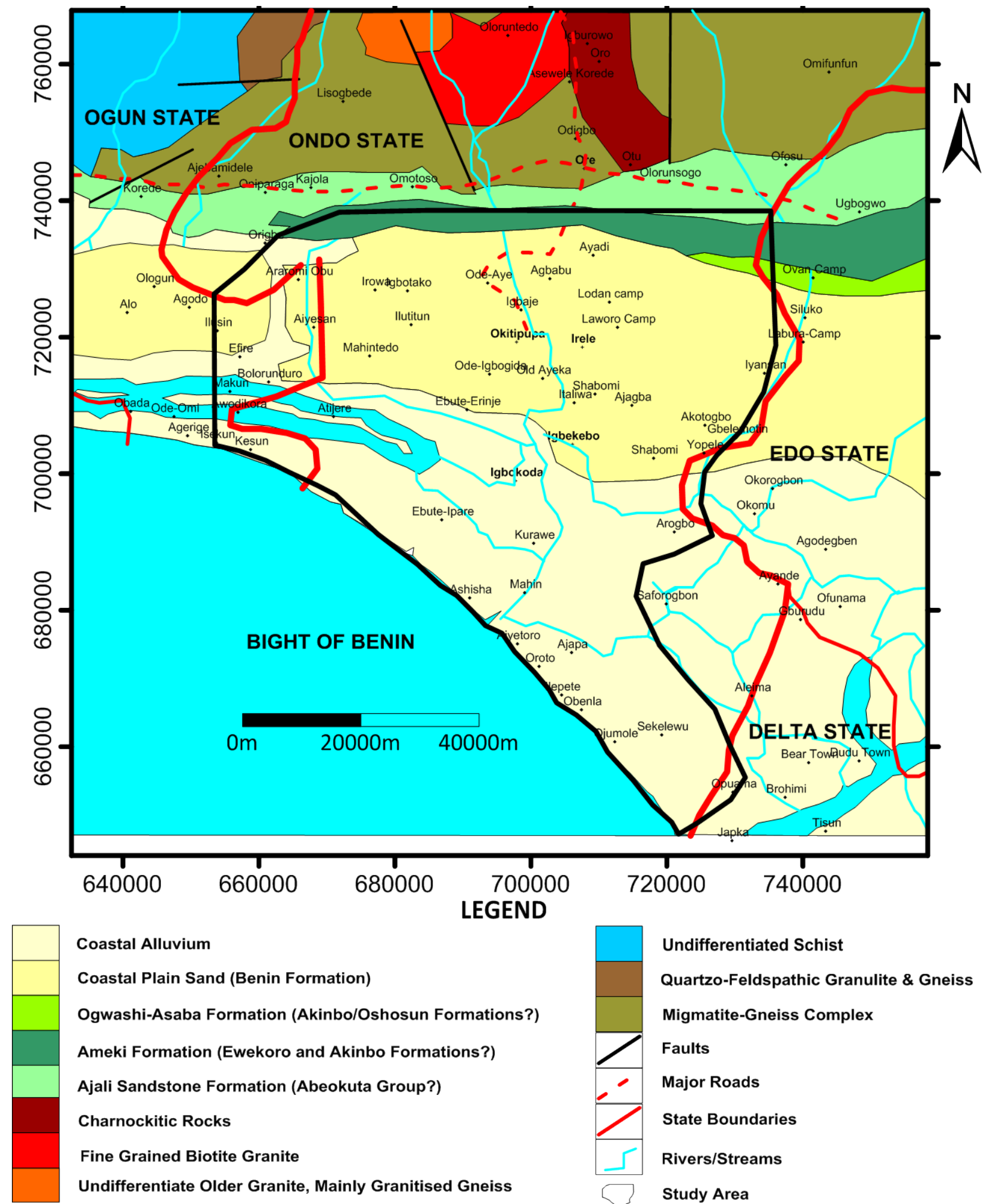

Coastal Alluvium

Coastal Plain Sand (Benin Formation)

Ogwashi-Asaba Formation (Akinbo/Oshosun Formations?)

Ameki Formation (Ewekoro and Akinbo Formations?)

Ajali Sandstone Formation (Abeokuta Group?)

Charnockitic Rocks

Fine Grained Biotite Granite

Undifferentiate Older Granite, Mainly Granitised Gneiss

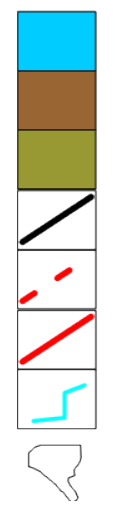

Undifferentiated Schist

Quartzo-Feldspathic Granulite \& Gneiss

Migmatite-Gneiss Complex

Faults

Major Roads

State Boundaries

Rivers/Streams

Study Area

Figure 3. Geological map of the study area [23].

layer resistivity values vary from 0.2 - 21,806, 0.2 - 36,762, $0.2-7958,0.4$ 14,243, 2 - 10,798, 9 - 5285 and 10 - 18,527 ohm-m in the topsoil, second, third, 
Table 1. Vertical electrical sounding results.

\begin{tabular}{|c|c|c|c|c|}
\hline VES NO & LOCATION & $\begin{array}{l}\operatorname{RESISTIVITY}(\Omega-\mathrm{m}) \\
\rho_{1 /} \rho_{2 /} \rho_{3} \ldots \ldots \ldots \rho_{\mathrm{n}}\end{array}$ & $\begin{array}{l}\text { THICKNESS (m) } \\
\mathrm{d}_{1} / \mathrm{d}_{2} / \mathrm{d}_{3} / \ldots \ldots \ldots . . . \mathrm{d}_{\mathrm{n}}\end{array}$ & $\begin{array}{l}\text { CURVE } \\
\text { TYPE }\end{array}$ \\
\hline 1 & Omi & $1274 / 646 / 6170 / 369 / 7$ & $0.7 / 8.9 / 28.1 / 165.3$ & HKQ \\
\hline 2 & Sabomi & $192 / 444 / 696 / 65 / 3763$ & 0.9/9.0/40.8/420.0 & $\mathrm{AKH}$ \\
\hline 3 & Igbotu & $796 / 2012 / 860 / 757 / 69$ & $0.8 / 5.4 / 81.6 / 9.2$ & KQQ \\
\hline 4 & Agadagba & $4681 / 1800 / 153 / 31$ & $1.5 / 2.0 / 247$ & $\mathrm{QH}$ \\
\hline 5 & Ijuosun & $76 / 118 / 290 / 1352 / 203$ & $0.9 / 1.9 / 17.9 / 65.2$ & AAK \\
\hline 6 & Akotogbo & $1349 / 2104 / 4745 / 1175 / 50$ & $0.6 / 5.9 / 38 / 80.8$ & AKQ \\
\hline 7 & Ajagba & $1232 / 2062 / 396 / 59$ & $1.4 / 23.3 / 73.7$ & KQ \\
\hline 8 & Igbekebo & $1333 / 631 / 1245 / 350 / 176$ & $0.6 / 4.2 / 19.0 / 80.6$ & HKQ \\
\hline 9 & Asisa & $0.6 / 0.8 / 1.9$ & $2.7 / 143.9$ & A \\
\hline 10 & Obenla & $1.6 / 0.2 / 24 / 124$ & $4.4 / 20.2 / 31.7$ & HA \\
\hline 11 & Igbobini & $1372 / 662 / 3328 / 411 / 195$ & 0.8/3.0/16.5/169.8 & HKQ \\
\hline 12 & Oluagbo & $3024 / 145 / 631 / 428 / 206 / 5285$ & $0.7 / 0.1 / 12.4 / 2.8 / 64.4$ & HKQ \\
\hline 13 & Irele & $709 / 142 / 876 / 8818 / 428 / 3243$ & $0.9 / 0.8 / 1.2 / 20.3 / 187.5$ & HAKH \\
\hline 14 & Laworo Camp & $157 / 762 / 386 / 4237 / 8522 / 119$ & $0.4 / 0.2 / 13.2 / 7.6 / 34.5$ & KHAK \\
\hline 15 & Lokaka Camp & $876 / 492 / 5844 / 878 / 1494$ & 1.0/1.0/1.4/116.5 & $\mathrm{HKH}$ \\
\hline 16 & Owode Road & $843 / 824 / 6165 / 790 / 21$ & $1.2 / 5.0 / 22.2 / 276.8$ & KKQ \\
\hline 17 & Okitipupa & $1543 / 898 / 5416 / 113$ & $0.9 / 8.3 / 45.1$ & HK \\
\hline 18 & Ikoya & $401 / 1276 / 41 / 568 / 4731$ & $0.5 / 1.7 / 0.5 / 25.9$ & KHA \\
\hline 19 & Ilutitun & $230 / 106 / 678 / 852 / 262$ & $0.8 / 7.8 / 10.6 / 43.6$ & HK \\
\hline 20 & Igbinsin Oloto & $4254 / 1128 / 3247 / 563$ & $1.0 / 7.4 / 77.5$ & HK \\
\hline 21 & Igboegbugurin & $10608 / 821 / 1314 / 356 / 10798$ & $0.8 / 5.3 / 18.6 / 25.4$ & $\mathrm{HKH}$ \\
\hline 22 & Itebu Kunmi & $21806 / 36762 / 2647 / 7925 / 1320$ & $0.7 / 1.0 / 15.6 / 134.2$ & QHK \\
\hline 23 & Mahintedo & $1298 / 190 / 7958 / 757 / 175$ & $0.8 / 0.7 / 10.8 / 89.9$ & HKQ \\
\hline 24 & Itebu Elero & $1457 / 476 / 1000 / 213 / 9675$ & $0.4 / 3.1 / 32.2 / 287.7$ & $\mathrm{HKH}$ \\
\hline 25 & Loda Camp & $197 / 3480 / 597 / 3739 / 623$ & $0.5 / 0.8 / 11.8 / 112.3$ & KHK \\
\hline 26 & Ayila & $350 / 1377 / 1121 / 291 / 56$ & $0.8 / 0.4 / 30.0 / 111.2$ & KQQ \\
\hline 27 & Aiyesan & $432 / 1154 / 392 / 2011 / 179$ & $0.8 / 1.5 / 2.7 / 62.0$ & KHK \\
\hline 28 & Lomiroro & $456 / 837 / 1258 / 2273 / 165$ & $0.8 / 5.2 / 11.3 / 49.3$ & AAK \\
\hline 29 & Efire & $56 / 1199 / 218 / 1551 / 434 / 82$ & $0.7 / 0.2 / 8.8 / 12.9 / 81.6$ & KHKQ \\
\hline 30 & Atijere & $3582 / 11265 / 4762 / 176 / 139$ & $0.8 / 0.6 / 8.1 / 93.5$ & KQQ \\
\hline 31 & Makun & 2023/4007/2978/119/84/139 & $0.7 / 2.8 / 7.0 / 13.1 / 97.4$ & $\mathrm{KQQH}$ \\
\hline 32 & Araromi-Obu & $2236 / 2592 / 6412 / 466 / 335$ & $0.9 / 13.5 / 51.0 / 24.9$ & AKQ \\
\hline 33 & Agbure & $1395 / 1296 / 2410 / 620 / 274 / 72$ & 1.3/3.5/24.7/14.7/123.7 & HKQQ \\
\hline 34 & Ilusin & 1055/236/9179/717/71 & $1.8 / 2.6 / 23.4 / 26.0$ & HKQ \\
\hline 35 & Abigi & $568 / 450 / 2084 / 297 / 56$ & $0.8 / 3.9 / 68.1 / 121.0$ & HKQ \\
\hline- & - & - & - & - \\
\hline 105 & Adagbakuja 2 & $0.9 / 0.6 / 0.9 / 7.4$ & $1.0 / 7.2 / 43.0$ & HA \\
\hline 106 & Oluagbo & Noisy data & & \\
\hline 107 & Agbabu 2 & Noisy data & & \\
\hline 108 & Igbobini 2 & Noisy data & & \\
\hline
\end{tabular}


fourth, fifth, sixth and seventh geoelectric layers respectively. The eighth geoelectric layer was delineated only at Ode Aye1 with resistivity value of $523 \mathrm{ohm}$ $\mathrm{m}$. Layer thicknesses across the study area vary respectively from $0.4-10.6,0.1-$ 58.6, 0.5 - 206, 1.7 - 423.5, 7.6 - 263 and $81.2-133.5 \mathrm{~m}$ in the topsoil, second, third, fourth, fifth and sixth geoelectric layers respectively. At Ode Aye1, the thickness value of the seventh layer is $15.2 \mathrm{~m}$. Thirty-five (35) different curve types were delineated across the study area (Figure 4) varying from simple to complex types.

\subsection{Geoelectric Sections}

Figure 5 shows the geoelectric section connecting Ajegunle, Igbinsin-Oloto, Orereara, Ileriayo, Oriopo, Apata Ijaw, Molutehin and Oretan along the northwest-southeast direction. Three to seven geoelectric layers were delineated across this section, which corresponds to four geologic layers; the topsoil (red sand), coastal alluvium (white sand), lateritic sand, clayey sand/mud-peat and sandy clay. This section reveals possible presence of brackish/saline water in Ileriayo, Oriopo, Apata-Ijaw and Oretan. This suspicion is based on the low resistivity values (below $60 \mathrm{ohm}-\mathrm{m}$ ) obtained within the coastal alluvium and clayey sand beneath these VES locations.

Figure 6 shows the geoelectric section connecting Atijere, Obe-Rebiminu, Zion, Temidire, Abaalala, Gbabijo, Asisa, Eruna, Ayetoro, Obenla, Awoye, Molutehin and Oretan along the southwest-southeast direction. Four to five geo-

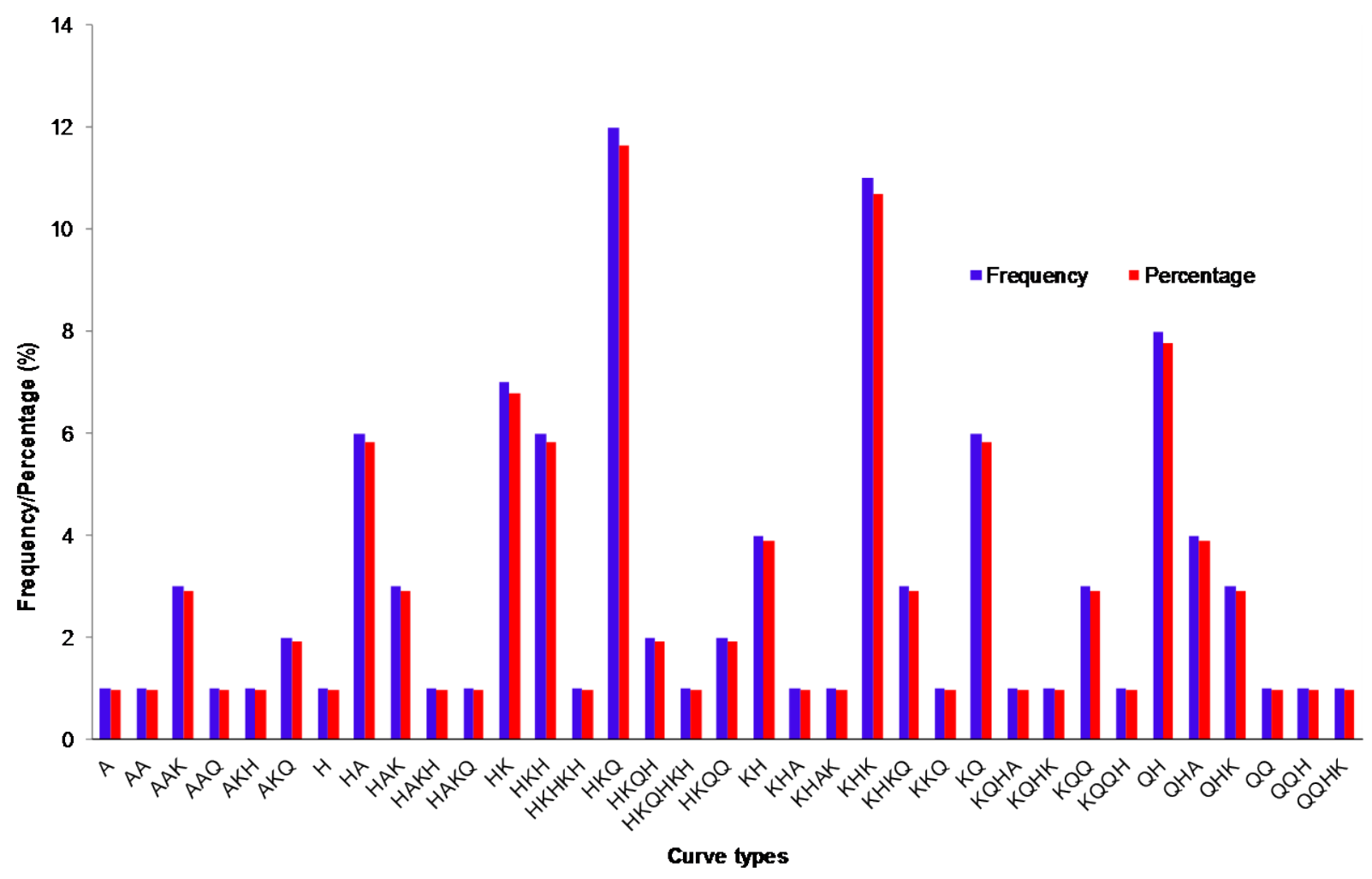

Figure 4. Curve types obtained from the study area and their rate of occurrence. 


\section{Tr1 (NW)}

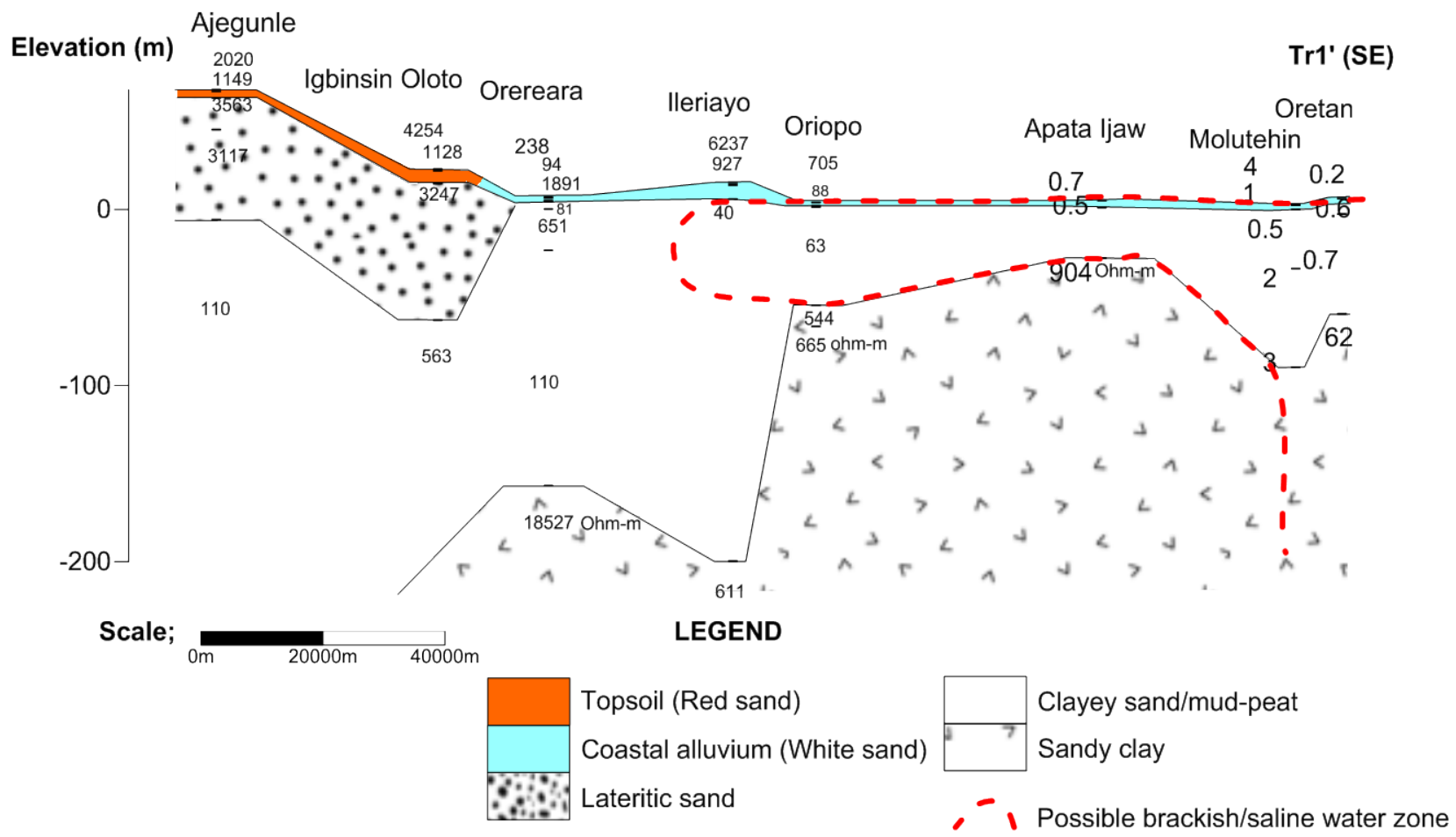

Figure 5. Geoelectric section along NW-SE direction.

Tr2 (SW)

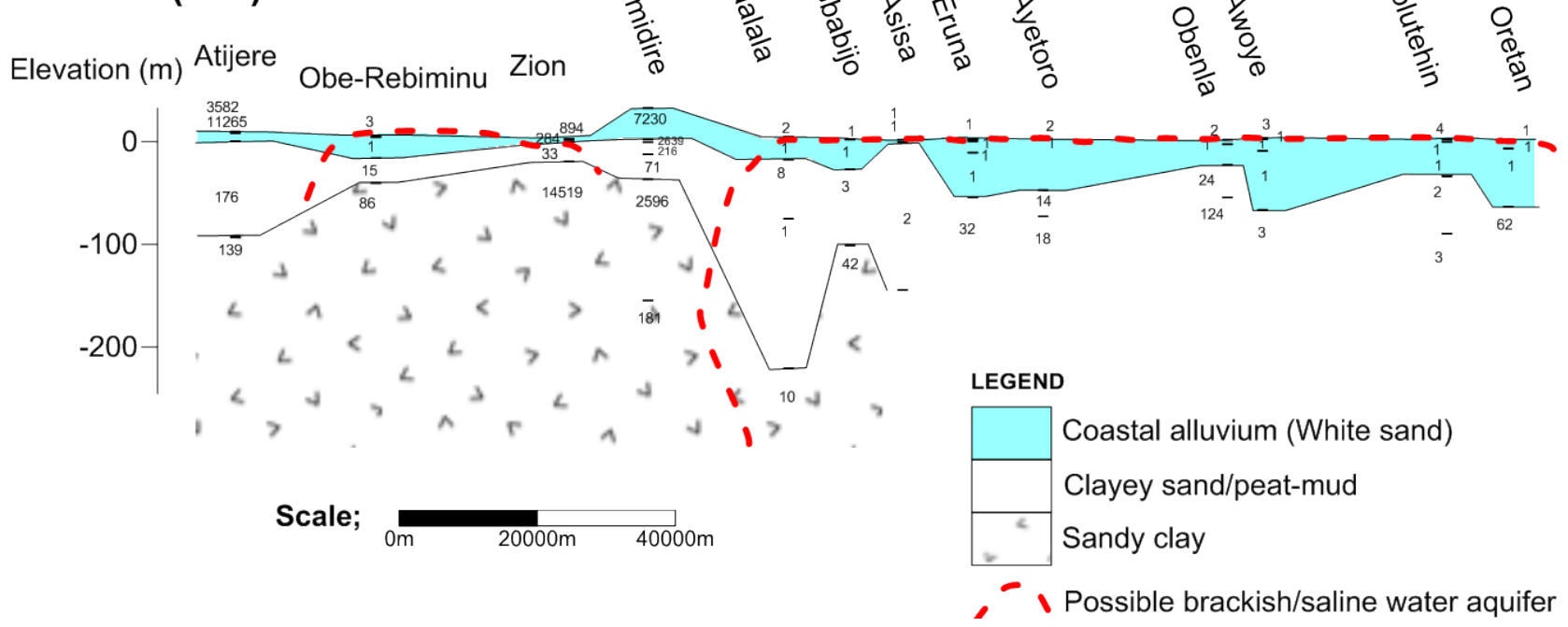

Figure 6. Geoelectric section along NW-SE direction.

electric layers were delineated across this section which corresponds to three geologic layers; coastal alluvium, clayey sand/mud-peat and sandy clay. Low resistivity values (mostly below $30 \mathrm{ohm}-\mathrm{m}$ ) were delineated within coastal alluvium and clayey sand beneath Obe-Rebiminu, Zion, Gbabijo, Asisa, Abaalala, Eruna, Ayetoro, Obenla, Awoye, Molutehin and Oretan. These low resistivity values are indicative of brackish/saline water. The proximity of these locations to 
the Atlantic Ocean is responsible for this saline intrusion.

The north-south geoelectric section (Figure 7) connecting Ominla, Oluagbo, Igodan Lisa 2, Igbokoda 2, Oriopo, Ugbo, Ugbonla and Ayetoro delineated very low resistivity values beneath Idepe, Ugbo, Ugbonla, Adagbakuja and Ayetoro. Four to six geoelectric layers were delineated across this sections and they corresponds to five geologic layers namely; topsoil (red sand) which gradually change to coastal alluvium towards the shore line, lateritic sand, sandy clay/ mud-peat and clayey sand. Low resistivities (1 - $60 \mathrm{ohm})$ typical of saline water intruded layer were delineated beneath Ugbo, Ugbonla and Ayetoro. Resistivities of all the layers delineated along this section decreases toward the shore, this suggest that the saline water intrusion mapped along this geoelectric section emanated from the Atlantic Ocean.

The second north-south geoelectric section (Figure 8) connects Loda, Ayadi, Legbogbo, Irele Road, Omi, Igbotu, Adagbakuja, Apata Ijaw and Awoye. Low resistive layers were delineated beneath Legbogbo, Irele road and Omi area. However the IPS results (Table 2) showed that low resistivities recorded in these areas are due to presence of clay layers beneath these VES locations. Towards the coast at Adagbakuja, Apata Ijaw and Awoye low resistivity values ( 1 - 3 ohm-m) were recorded, indicating possible presence saline water within the coastal alluvium, sandy clay/mud-peat and clayey sand layers.

\subsection{Aquifer Layers}

The aquifer layers across the study area were identified and presented as resistivity and depth maps.

$\operatorname{Tr} 3$ (N)

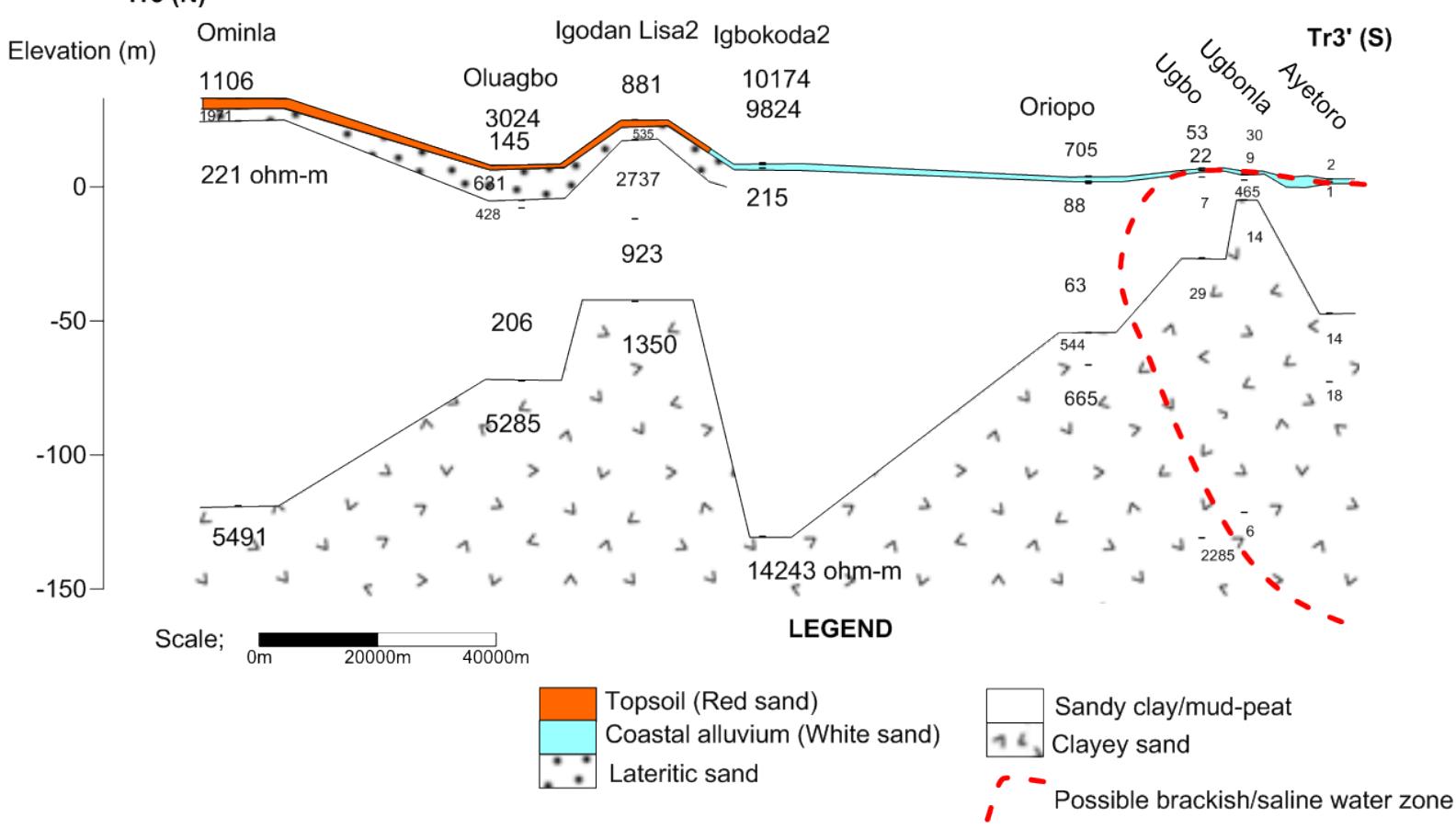

Figure 7. Geoelectric section along N-S direction. 
$\operatorname{Tr} 4$ (N)

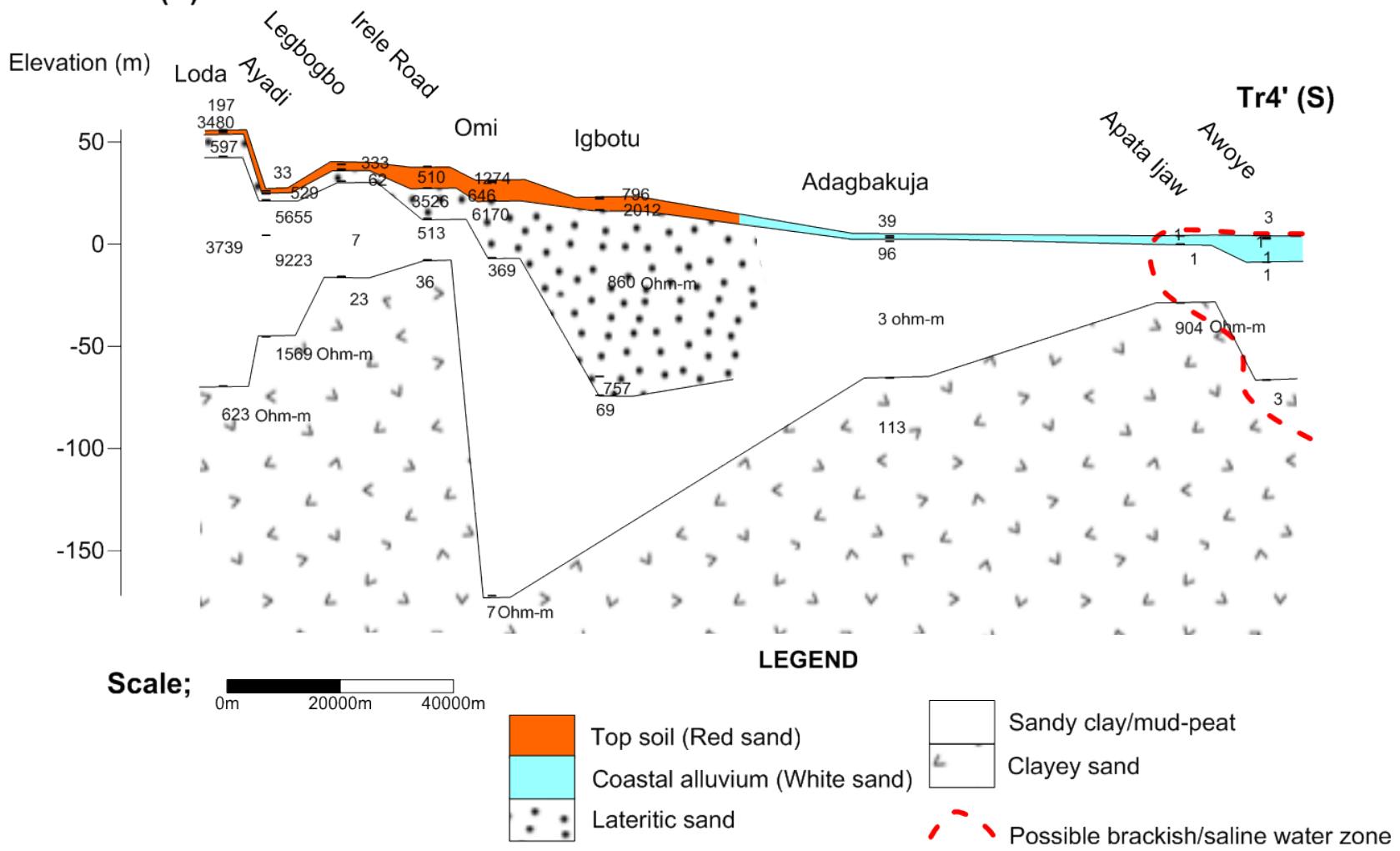

Figure 8. Geoelectric section along N-S direction.

Table 2. Correlation of VES and IPS results.

\begin{tabular}{|c|c|c|c|c|}
\hline VES NO & LOCATION & $\begin{array}{c}\text { RESISTIVITY }(\Omega-\mathrm{m}) \\
\rho_{1} / \rho_{2} / \rho_{3} \ldots \ldots \ldots \rho_{\mathrm{n}}\end{array}$ & $\begin{array}{l}\text { THICKNESS (m) } \\
\mathrm{h}_{1} / \mathrm{h}_{2} / \mathrm{h}_{3} / \ldots \ldots \ldots \mathrm{h}_{\mathrm{n}}\end{array}$ & $\begin{array}{c}\text { DEPTH (m) } \\
\mathrm{d}_{1} / \mathrm{d}_{2} / \mathrm{d}_{3} / \ldots \ldots \ldots \mathrm{d}_{\mathrm{n}}\end{array}$ \\
\hline 96 & Legbogbo & $347 / 98 / 535 / 106 / 7362$ & $1.0 / 2.2 / 14.2 / 55.2$ & $1.0 / 3.2 / 17.4 / 72.6$ \\
\hline 97 & Omi & $637 / 238 / 3828 / 417$ & $0.5 / 5.3 / 19.8$ & $0.5 / 5.8 / 25.6$ \\
\hline 98 & Iyansan Road & $125 / 4573 / 1285 / 19$ & $2.6 / 18.3 / 31.2$ & $2.6 / 20.9 / 52.1$ \\
\hline 99 & Agadagba & $2968 / 65 / 9927 / 244$ & $1.6 / 2.1 / 40.2$ & $1.6 / 3.7 / 43.9$ \\
\hline 100 & Ayeka & $1058 / 303 / 1717 / 1422 / 457 / 33$ & $0.8 / 1.8 / 5.5 / 0.8 / 127.4$ & $0.8 / 2.6 / 8.1 / 8.9 / 136.3$ \\
\hline 101 & Obinehin & $2051 / 80 / 38 / 3241$ & $0.7 / 2.4 / 22.4$ & $0.7 / 3.1 / 25.5$ \\
\hline 102 & Zion Pepe & $894 / 284 / 33 / 14519$ & $0.9 / 2.3 / 29.5$ & $0.9 / 3.2 / 32.7$ \\
\hline 103 & Odeaye & $973 / 270 / 1077 / 279 / 37 / 16012$ & $1.0 / 0.7 / 8.4 / 27.6 / 67.9$ & $1.0 / 1.7 / 10.1 / 37.6 / 105.5$ \\
\hline 104 & Agbabu & $701 / 62 / 286 / 4459$ & $3.2 / 6.2 / 38.4$ & $3.2 / 9.4 / 47.8$ \\
\hline IPS NO & LOCATION & $\begin{array}{l}\text { CHARGEABILITY (msec) } \\
\text { M }_{1} / M_{2} / M_{3} \ldots \ldots \ldots M_{n}\end{array}$ & $\begin{array}{l}\text { THICKNESS (m) } \\
\mathrm{h}_{1} / \mathrm{h}_{2} / \mathrm{h}_{3} / \ldots \ldots \ldots \mathrm{h}_{\mathrm{n}}\end{array}$ & $\begin{array}{c}\text { DEPTH (m) } \\
\mathrm{d}_{1} / \mathrm{d}_{2} / \mathrm{d}_{3} / \ldots \ldots \ldots \mathrm{d}_{\mathrm{n}}\end{array}$ \\
\hline 1 & Legbogbo & $1 / 4.2 / 1 / 1.8 / 9 / 42 / 180$ & $0.6 / 1.7 / 3.3 / 1.0 / 11.3 / 29.1$ & $0.6 / 2.3 / 5.6 / 6.6 / 17.9 / 47.1$ \\
\hline 2 & Omi & $0.3 / 1.2 / 0.7 / 5.2 / 109$ & $0.3 / 1.7 / 12.7 / 19.1$ & $0.3 / 2.0 / 14.7 / 33.8$ \\
\hline 3 & Iyansan Road & $1 / 6 / 0.3 / 5 / 36 / 577$ & $3.1 / 5.4 / 3.4 / 11.8 / 24.9$ & $3.1 / 8.5 / 12.0 / 23.8 / 48.7$ \\
\hline 4 & Agadagba & $4 / 2.4 / 17 / 25 / 35 / 8105$ & $0.8 / 1.6 / 2.3 / 6.5 / 29.1$ & $0.8 / 2.4 / 4.7 / 11.1 / 40.2$ \\
\hline 5 & Ayeka & $1 / 2 / 23 / 158 / 317$ & $0.5 / 12.2 / 15.3 / 93.7$ & $0.5 / 12.7 / 28.0 / 121.7$ \\
\hline 6 & Obinehin & $1.3 / 16 / 17 / 9 / 53 / 505$ & $0.5 / 3.8 / 7.0 / 20.9 / 26.2$ & $0.5 / 4.4 / 11.4 / 32.3 / 58.4$ \\
\hline 7 & Zion Pepe & $4 / 11 / 140 / 315 / 894$ & $4.3 / 0.3 / 12.0 / 16.0$ & $4.3 / 4.6 / 16.6 / 32.6$ \\
\hline 8 & Odeaye & $973 / 270 / 1077 / 294 / 37 / 1601$ & $1.4 / 0.7 / 1.4 / 34.5$ & $1.4 / 2.1 / 3.5 / 37.9$ \\
\hline 9 & Agbabu & $2 / 16 / 118 / 970 / 123$ & $1.1 / 1.1 / 3.3 / 57.6$ & $1.1 / 2.3 / 5.6 / 63.2$ \\
\hline
\end{tabular}


The resistivity of the first aquifer layer (Figure 9) varies from 0.2 (Obenla) to 1569 ohm-m (Ayadi). In the coastal areas and Agbabu, Ilubirin and part of Ode Aye in the northern part of the study area, the resistivity values fall below 60 ohm-m, suggesting that the shallow aquifers in these locations might contain brackish or saline water. The IP sounding results (Table 2) give low chargeability values within the low resistive layer at Agbabu, but high value at Ode Aye, thereby confirming possible saline water intrusion only in Agbabu. That saline water exists in Agbabu was equally attested to by hydrochemical analysis earlier carried out across the study area [11] [24]. The depth to first aquifer layer ranges from 0.7 (Eruna and Molutehin) to $151.5 \mathrm{~m}$ (Itebukunmi). The depth to first aquifer layer map ((Figure 10) shows that depth to first aquifer layer is generally shallow (less than $5 \mathrm{~m}$ ) in the coastal area and generally water logged. The first aquifer unit in this area is highly susceptible to anthropogenic pollutants due to its shallow nature and possible poor protection by the overlying sandy layers.

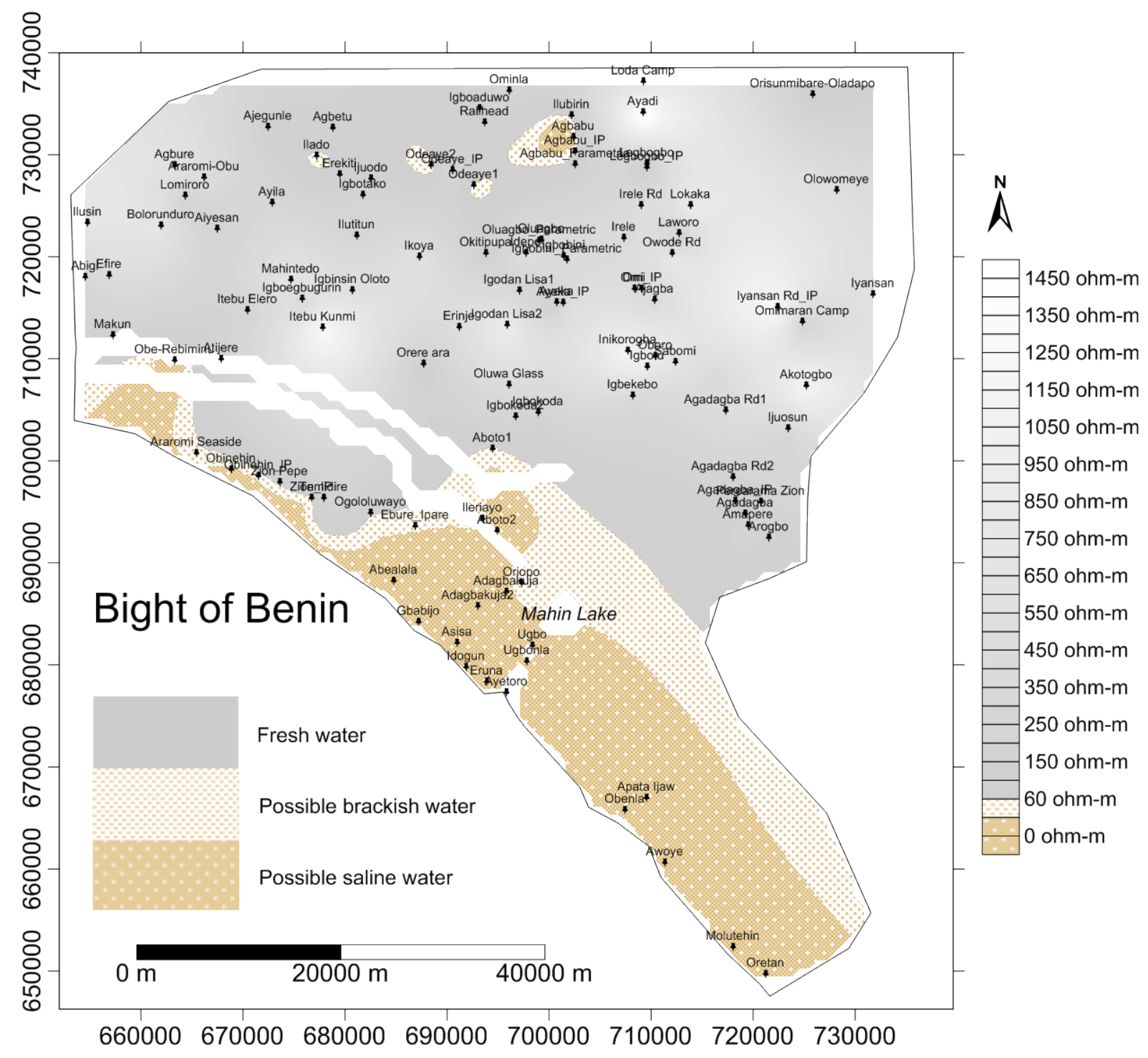

Figure 9. First aquifer layer resistivity map. 


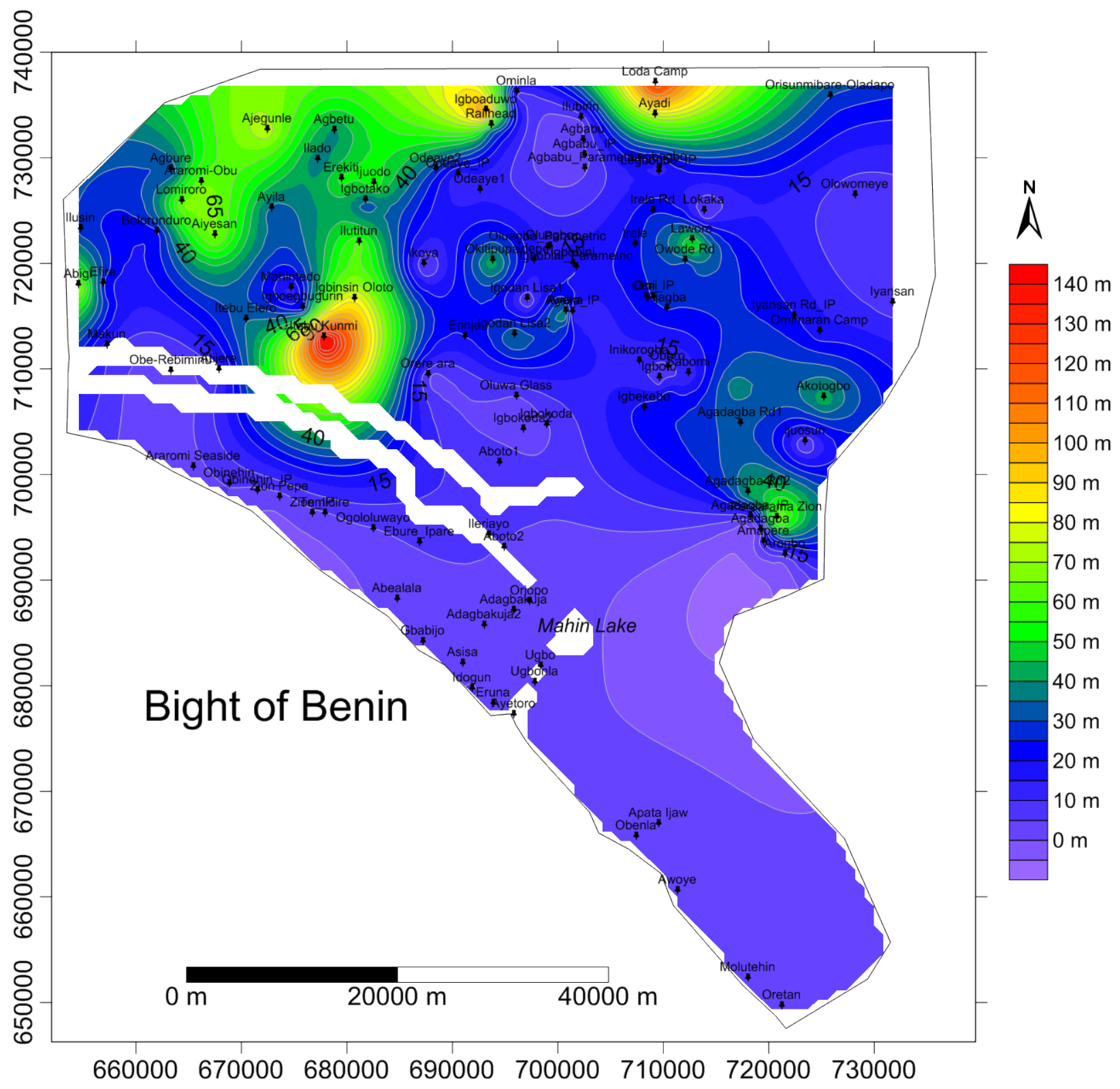

Figure 10. Depth to first aquifer layer map.

The resistivity of the second aquifer layer (Figure 11) varies from 0.5 (Molutehin) to 904 ohm-m (Apata Ijaw). The low resistivity values along this aquifer extends only to some coastal towns, such as Obe-Rebiminu, Eruna, Ugbo, Gbabijo, Adagbakuja, Abealala, Awoye, Ugbonla, Araromi seaside, Ayetoro, Molutehin and Oretan. It also extends to the north eastern area of Owode, Iyansan, Agadagba, Laworo, Legbogbo, Lokaka, and Irele and including Ode Aye, Oluagbo, Okitipupa and Idepe in the north central part of the area. The IP sounding results (Table 2) again shows high chargeability values at Odeaye, Iyansan road and Agadagba thereby eliminating the possibility of saline water within the second aquifer layer within the northeastern area. The depth to second aquifer across the study area varies from 1.4 (Awoye) to $305.5 \mathrm{~m}$ (Owode 


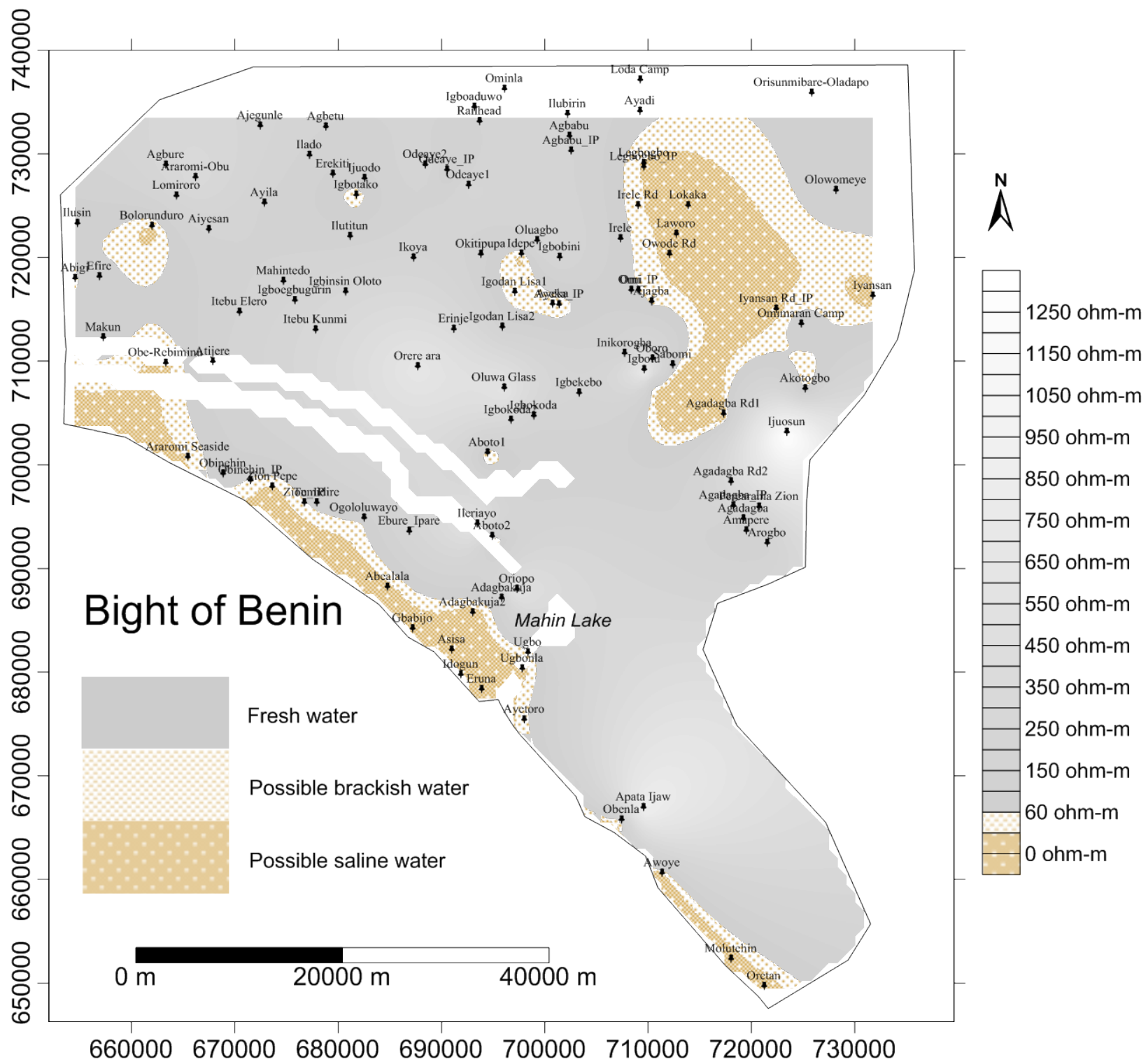

Figure 11. Second aquifer layer resistivity map.

road). The map showing depth to second aquifer layer (Figure 12) indicates that depth to this aquifer layer is shallow (less than $23 \mathrm{~m}$ ) in some part of the coastal areas, such as Obe-Rebiminu, Araromi Seaside, Temidire, Ugbonla, Ayetoro, Awoye, Molutehin and Oretan. Likewise in some places in the mainland the intermediate aquifer also exists at shallower depths. Some of these areas are closer to streams and river tributaries which are directly or indirectly connected to the sea water. This explains the possible brackish/saline water suspected in these areas.

The resistivity of the third aquifer unit (Figure 13) varies from 0.4 (Eruna) to $665 \mathrm{ohm}-\mathrm{m}$ (Oriopo). The low resistivity values along this layer extends to Araromi seaside, Obinehin, Gbabijo, Adagbakuja, Ugbonla, Eruna, Ayetoro, Awoye and Molutehin in the coastal area. This is indicative of saline water intrusion in this area. However in the northeastern part of the mainland, low resistivity val- 


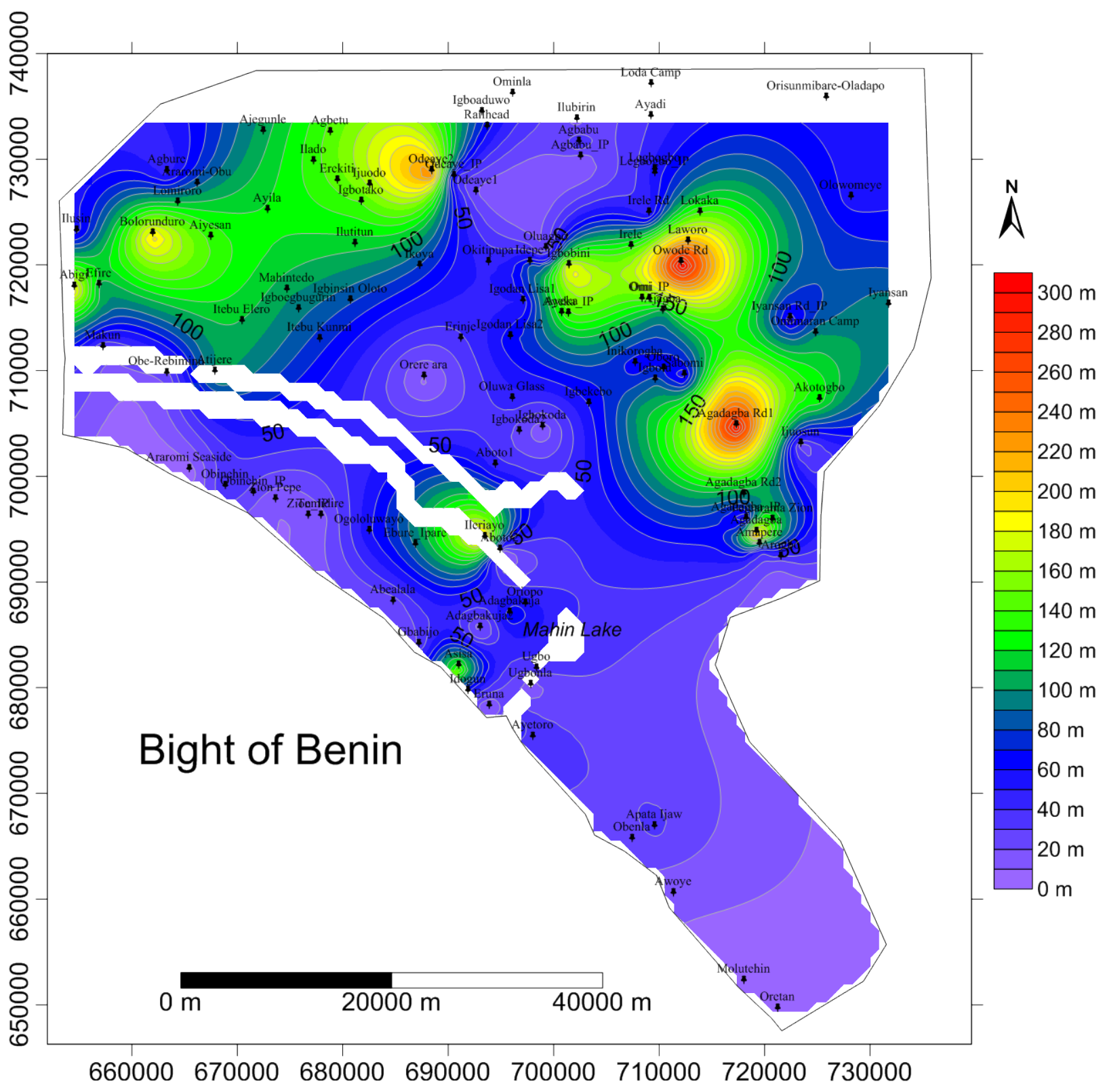

Figure 12. Depth to second aquifer layer map.

ues were delineated in many places such as: Ayadi, Legbogbo, Irele road, Lokaka, Laworo, Agadagba, Arogbo and Amapere. This probably suggests that aquifers in this area contain brackish to saline water. Again the IP sounding results nullified any suspicion of occurrence of brackish/saline water intrusion in these areas, based on high chargeability values obtained from these area.

The depth to the third aquifer layer (Figure 14) ranges from 12.9 (Awoye) to $452.9 \mathrm{~m}$ (Arogbo). The depth to the third aquifer layer is generally significant (about $100 \mathrm{~m}$ ) in most parts of the coastal towns and mainland with the exceptions of Zion, Temidire, Ogoluwayo, Ebute Ipare and Abealala, in the western and eastern parts of the study area. 


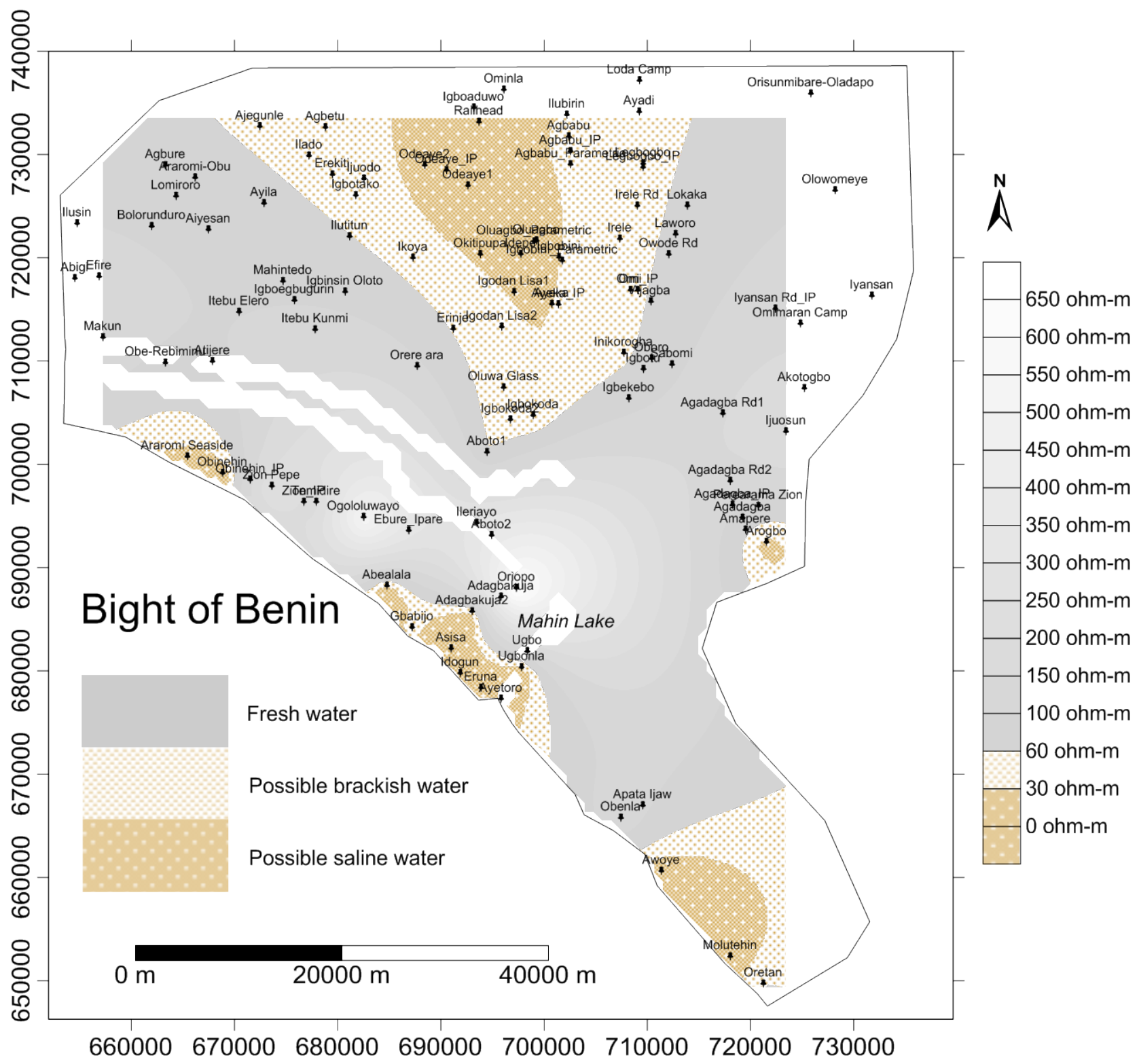

Figure 13. Third aquifer layer resistivity map.

\subsection{Average Longitudinal Resistivity}

Average longitudinal resistivity; a second order geoelectric parameter was calculated from the primary geoelectric parameters and presented as map (Figure 15). The map enabled the delineation of lateral extent of saline water intrusion across the study area based on resistivity values. Low resistivity values (less than $60 \mathrm{ohm}-\mathrm{m}$ ) were considered to be brackish to saline water intruded zone.

\subsection{Saline Water Extent}

Saline map showing the extent of saline water into areas (Figure 16) was generated based on the three aquifer layer maps and the average longitudinal resistivity map. The map project possible extents of saline water intrusion across the study area. The map shows that the southeastern part are the largely affected by 
saline water intrusion, this perhaps due to the fact that there are more tributaries in this area through which sea water can move land ward.

\subsection{Depth to Saline Water Predictive Model}

Strong correlation was also observed between the depth to the saline water in a given location and the distance from salinity source; Ocean, tributaries, canals, streams or rivers bearing saline water (Figure 17). Where a location is close to the source of saline water, the depth to the saline water will be shallow and conversely where the location is far from salinity source depth to the saline water will be deeper. The correlation curve (Figure 17) shows a strong direct correlation $\left(r^{2}=0.8564\right)$ between distance of location from the saline water source and

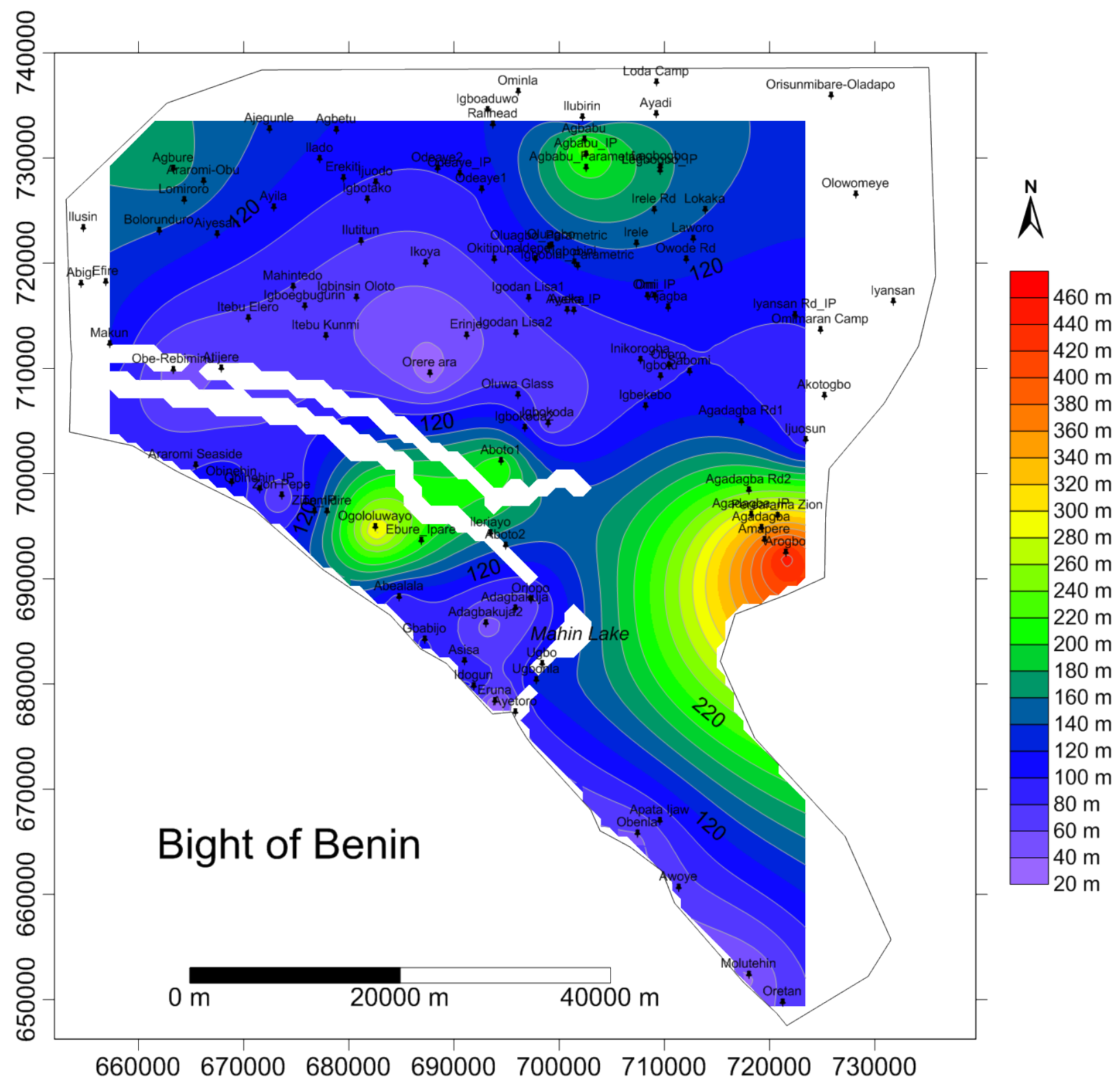

Figure 14. Depth to third aquifer layer map. 


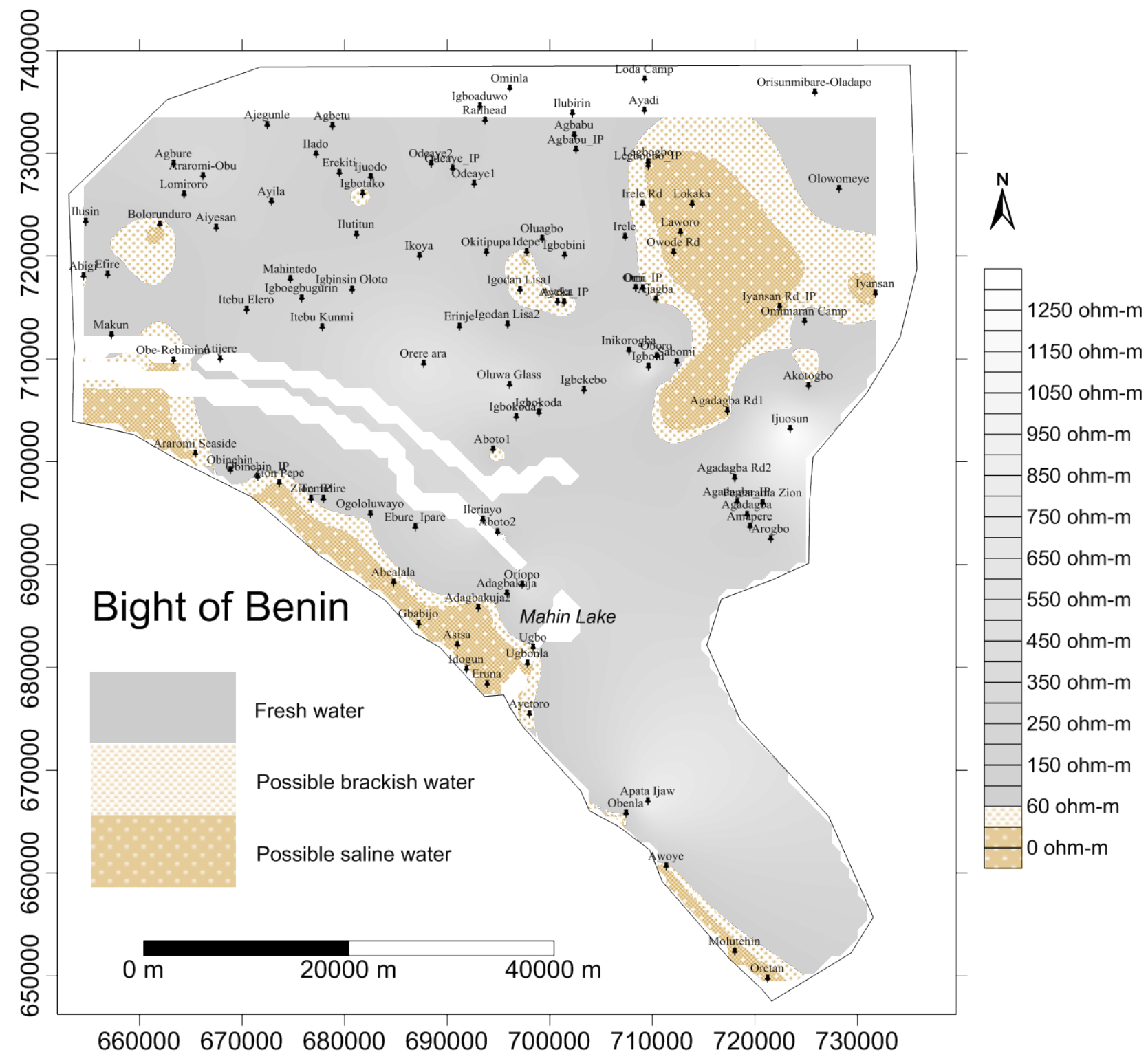

Figure 15. Average longitudinal resistivity map.

depth to saline water. This can therefore serve as a predictive model to determine depth to saline water at any location within the saline water zone in the study area.

\section{Conclusion}

This study has revealed the presence and extent of saline water intrusion in the coastal areas and Agbabu in the north central part of the study area, and this probably suggests presence of connate water. Aquifer layers in the coastal area also exist at shallow depths which makes these aquifers highly susceptible to surface pollution in addition to the fact that their proximity to the oceans makes them highly vulnerable to saline water intrusion. 


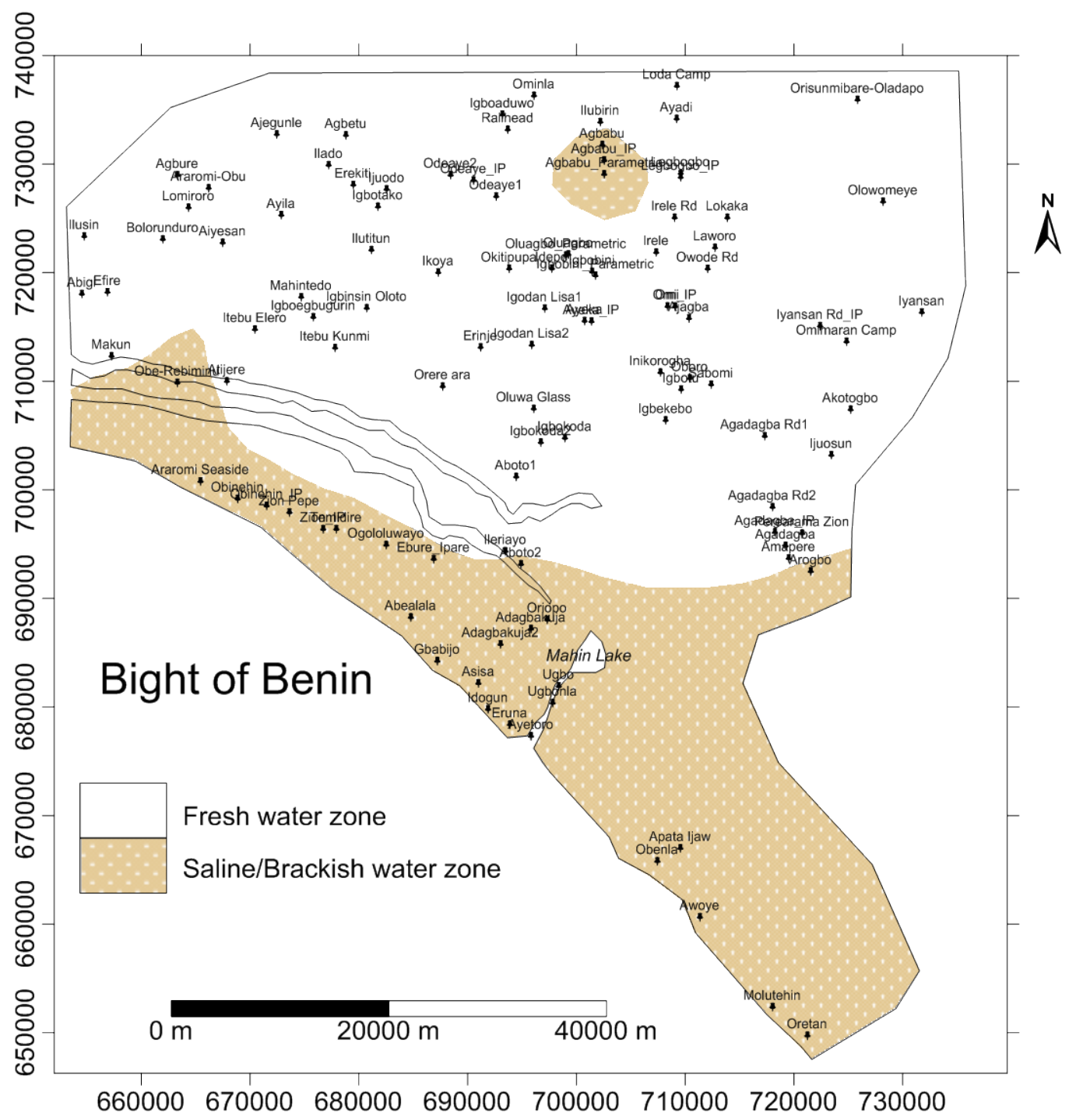

Figure 16. Saline water extent map.

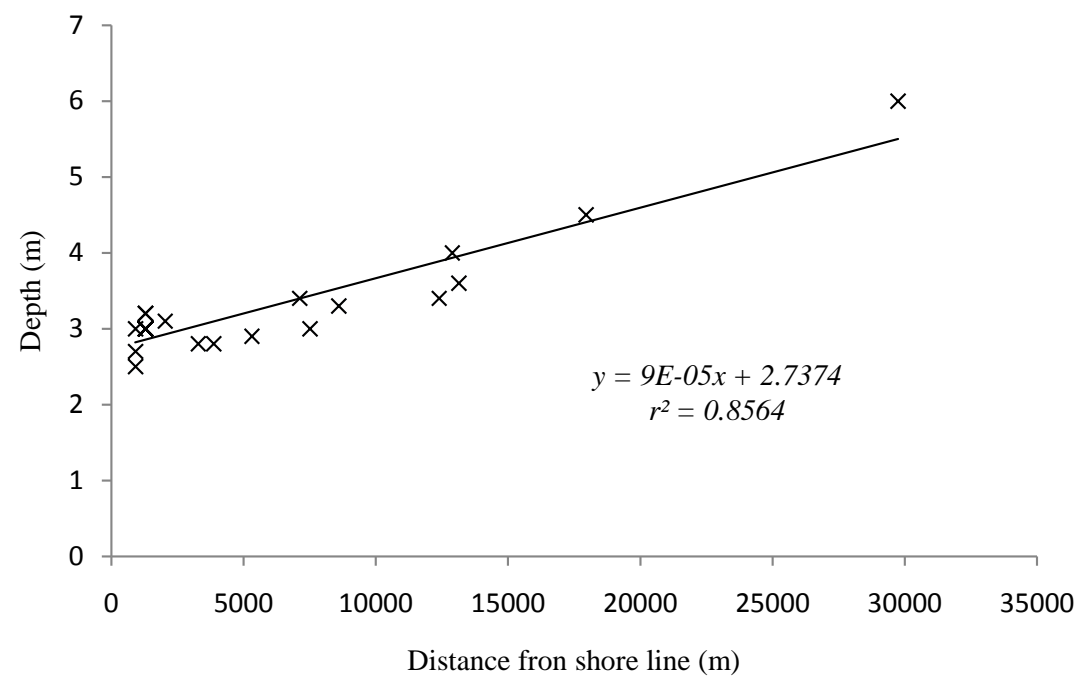

Figure 17. Depth to saline water and distance from salinity source correlation curve. 


\section{Acknowledgements}

The authors wish to acknowledge the following students of the Department of Applied Geophysics FUTA, who assisted during the field work stage of this work, Olemu Ogheneochuko, Orekoya Abimbolu, Oghene Ortega, Oduwaye Aron, Olaogun Oluwole, Oloriegbe Olatubosun, Ologun, B.J., Amosun Joel, Obamoyegun Niyi, Akinsola Samson, Egbukuyomi Pat, Abiola Adekunle and others.

\section{References}

[1] Batayneh, A.T. (2006) Use of Electrical Resistivity Methods for Detecting Subsurface Fresh and Saline Water and Delineating Their Interfacial Configuration: A Case Study of the Eastern Dead Sea Coastal Aquifers, Jordan. Hydrogeology Journal, 14, 1277-1283. https://doi.org/10.1007/s10040-006-0034-3

[2] Bauer, P., Supper, R., Zimmermann, S. and Kinzelbach, W. (2006) Geoelectrical Imaging of Groundwater Salinization in the Okavango Delta, Botswana. Journal of Applied Geophysics, 60, 126-141. https://doi.org/10.1016/j.jappgeo.2006.01.003

[3] Chachadi, A.G. (2005) Seawater Intrusion Mapping Using Modified Galdit Indicator Model-Case Study in Goa. Jalvigyan Sameeksha, 20, 29-45.

[4] Choudhury, K., Saha, D.K. and Chakraborty, P. (2001) Geophysical Study of Saline Water Intrusion in a Coastal Alluvial Terrain. Journal of Applied Geophysics, 46, 189-200. https://doi.org/10.1016/S0926-9851(01)00038-6

[5] Jansen, J.R. (2011) Geophysical Methods to Map Brackish and Saline Water in Aquifers. Proceedings of the 2011 Georgia Water Resources Conference, Athens, 11-13 April 2011, 4.

[6] Khalil, M.H. (2006) Geoelectric Resistivity Sounding for Delineating Saltwater Intrusion in the Abu Zenim Area, West Sinai, Egypt. Journal of Geophysics and Engineering, 3, 24-251. https://doi.org/10.1088/1742-2132/3/3/006

[7] Martinez-Retama, S., Flores, C. and Castillo-Gurrola, J. (2007) Saline Intrusion in Guaymas Valley, Mexico from Time-Domain Electromagnetic Soundings. Geofisica International, 46, 175-198.

[8] Satriani, A., Loperte, A. and Proto, M. (2011) Electrical Resistivity Tomography for Coastal Salt Water Intrusion Characterization along the Ionian Coast of Basilicata Region, Southern Italy. IWTC-15, $15^{\text {th }}$ International Water Technology Conference, Alexandria, 31 March-2 April 2011, 12.

[9] Samsudin, A.R., Haryono, A., Hamzah, U. and Rafek, A.G. (2008) Salinity Mapping of Coastal Groundwater Aquifers Using Hydrogeochemical and Geophysical Methods: A Case Study from North Kelantan, Malaysia. Environmental Geology, 55, 1737-1743. https://doi.org/10.1007/s00254-007-1124-9

[10] Rahaman, M.M. and Bhattacharya, A.K. (2014) Saline Water Intrusion in Coastal Aquifer: A Case Study from Bangladesh. Journal of Engineering, 4, 7-13.

[11] Omosuyi, G.O. (2001) Geophysical and Hydrogeological Investigations of Groundwater Prospects in the Southern Part of Ondo State, Nigeria. Ph.D. Thesis, Department of Applied Geophysics, Federal University of Technology, Akure, 195.

[12] Omosuyi, G.O., Ojo, J.S. and Olorunfemi, M.O. (2008) Geoelectric Sounding to Delineate Shallow Aquifers in the Coastal Plain Sands of Okitipupa Area, Southwestern Nigeria. The Pacific Journal of Science and Technology, 9, 562-577.

[13] Omoyoloye, N.A., Oladapo, M.I. and Adeoye, O.O. (2008) Engineering Geophysical Study of Adagbakuja Newtown Development SW, Nigeria. Medwell Online Journal 
of Earth Sciences, 2, 55-63.

[14] Adepelumi, A.A. (2008) Delineation of Saltwater Intrusion into the Freshwater Aquifer of Lekki Peninsula, Lagos, Nigeria. The 3rd International Conference on Water Resources and Arid Environments (2008) and the 1st Arab Water Forum, Riyadh, 16-19 November 2008, 15.

[15] Adeoti, L., Alile, O.U. and Uchegbulam, O. (2010) Geophysical Investigation of Saline Intrusion into Freshwater Aquifers: A Case Study of Oniru, Lagos State. Scientific Research and Essays, 5, 248-259.

[16] Oyedele, K.F. and Momoh, E.I. (2009) Evaluation of Seawater Intrusion in Freshwater Aquifers in a Lagoon Coast: A Case Study of the University of Lagos Lagoon, Akoka, Nigeria. New York Science Journal, 2, 32-42.

[17] Ayolabi, E.A., Folorunso, A.F., Odukoya, A.M. and Adeniran, A.E. (2013) Mapping Saline Water Intrusion into the Coastal Aquifer with Geophysical and Geochemical Technique: The University of Lagos Campus Case (Nigeria). SpringerPlus, 2, 1-14. https://doi.org/10.1186/2193-1801-2-433

[18] Jones, H.A. and Hockey, R.D. (1964) The Geology of Part of Southwestern Nigeria. Bulletin (Geological Survey of Nigeria), 31, 87.

[19] Burke, K.C., Dessauvagie, J.F.T. and Whiteman, A.J. (1971) The Opening of the Gulf of Guinea and the Geological History of the Benue Depression and Niger Delta. Nature, 233, 51-55. https://doi.org/10.1038/physci233051a0

[20] Klemme, H.D. (1975) Geothermal Gradient Heat Flow and Hydrocarbon Recovery. In: Fischer, A.G. and Judson, S., Eds., Petroleum and Global Tectonics, Princeton University Press, Princeton, 25-304.

[21] Whiteman, A.J. (1982) Nigeria: Its Petroleum Geology, Resources and Potential. Graham and Trottam, London, 394. https://doi.org/10.1007/978-94-009-7361-9

[22] Okosun, E.A. (1998) Review of the Early Tertiary Stratigraphy of Southwestern Nigeria. Journal of Mining and Geology, 34, 27-35.

[23] Petroleum Trust Fund (1997) Geological Map of Ondo State: National Rural Water Supply Project. The Petroleum (Special) Trust Fund (PTF).

[24] Adeyemo, I.A., Omosuyi, G.O. and Adelusi, A.O. (2015) Hydrochemical Investigation of Saline Water Intrusion into Aquifers in Part of Eastern Dahomey Basin, SW Nigeria. Journal of Environment and Earth Science (JEES), 5, 176-190.

\section{Submit or recommend next manuscript to SCIRP and we will provide best service for you:}

Accepting pre-submission inquiries through Email, Facebook, LinkedIn, Twitter, etc. A wide selection of journals (inclusive of 9 subjects, more than 200 journals)

Providing 24-hour high-quality service

User-friendly online submission system

Fair and swift peer-review system

Efficient typesetting and proofreading procedure

Display of the result of downloads and visits, as well as the number of cited articles

Maximum dissemination of your research work

Submit your manuscript at: http://papersubmission.scirp.org/

Or contact gep@scirp.org 